\title{
Breaking away from Capital? Theorising activity in the shadow of Marx
}

\author{
Peter E Jones \\ Communication Studies, Sheffield Hallam University \\ Sheffield, S1 1WB, United Kingdom \\ E-mail: P.E.Jones@shu.ac.uk
}

\begin{abstract}
The paper reflects on the relationship between the understanding of human activity which Marx expresses in Capital and the theoretical model of activity offered by an influential contemporary variant of Activity Theory. The paper argues that this variant departs significantly from Marx's conception of human activity and its role in what he calls the 'labour process'. In particular, Activity Theory has failed to distinguish between the labour process and the valorization process, a distinction which is fundamental to Capital and to Marx's theoretical and political perspective more generally. The paper also argues that this conceptual conflation is also evident in the theoretical discourse of the founders of the Activity Theory tradition. The paper goes on to consider the theoretical and practical implications of this departure from the method and conclusions of Capital.
\end{abstract}

\section{Introduction ${ }^{1}$}

Are Marx's ideas relevant to researchers in the cultural-historical and Activity Theory (CHAT) tradition today? And if so, how exactly are they

\footnotetext{
${ }^{1}$ In this paper I take up once again the themes which I have addressed in more depth in a number of unpublished papers (Jones, 2003, 2004) which have been circulating amongst colleagues and friends for some years and have been the basis of conference contributions in different venues, including at the first ISCAR conference in Seville and, most recently, the symposium in Oslo organised by Ines Langemeyer. I would like to thank a number of people who have commented on them: Chik Collins, Ines Langemeyer, Anna Stetsenko, Andrew Brown, Seth Chaiklin, David Bakhurst, Jan Derry, Reijo Miettinen, Paul Warmington, and Colin Barker. Jones (2004) has now recently appeared in Russian translation as Jones (2009), for which I am indebted to my friend Andrey Maidansky. I would like to give special thanks to Ines Langemeyer for inviting me to participate in the Oslo symposium and for her help and advice with this paper. I would also like to express my gratitude to an anonymous reviewer for a most helpful and constructive commentary which I'm afraid I've been unable to do justice to fully on this particular occasion.
} 
relevant? These are not only interesting but also important questions and ones which I believe we must squarely address as a research community. No less important, but more difficult, however, is the follow-up question: assuming that Marx's ideas are still relevant, are the aims, concepts and theoretical presuppositions of Activity Theory today consistent with his ideas? On this question, opinion seems to be divided amongst those researchers who are keen to reaffirm the Marxian roots and orientation of CHAT. Some scholars (Adler, 2006, 2007; Sawchuk, 2006) see a continuity and compatibility between Marx's analysis of capitalist production and the analytical framework of Activity Theory. By contrast, others (Jones, 2001, 2003, 2004, 2009; Langemeyer \& Roth, 2006; Avis, 2007; Warmington, 2008) detect a serious rift between Activity Theory and the Marxist tradition. I hope to explain here why I think the second group of authors has it right. ${ }^{2}$

Of course, it could be argued that a turning away from Marx and, in particular, a breaking away from Capital, is a good move and a timely one. Maybe it's time to settle accounts with Marxism, to bring our theory up-to-date and reorient ourselves on a different basis? But it is unclear as yet on what basis we might do this and what we might lose in the process. Maybe there is still something we can learn from Marx's Capital, as Ilyenkov, one of the most frequently cited philosophers in the Marxist tradition, argues insistently (Ilyenkov, 1982).

This paper is intended as a further contribution to the debate which is developing on this issue.

\footnotetext{
${ }^{2}$ Newman \& Holzman (1993) are probably the first authors to raise this issue, and in characteristically forthright style: "Activity theory, the psychological perspective with which Vygotsky is associated, partially originated with Marx's radically monistic and revolutionary conception of activity. Yet while most contemporary activity theorists acknowledge Marx as, if not the only founder, then one of the founders of activity theory, on our view most do not even remotely understand the revolutionary character of Marx's practical-critical conception of practical-critical activity" (1993, p. 14)
}

Specifically, I will argue that the methods and key concepts of one current, and very influential, version of Activity Theory developed by Yrjö Engeström and his co-workers and colleagues (e.g., Engeström, 1990; Engeström \& Miettinen, 1999; Miettinen, 2000), imply a significant departure from Marx's Capital, and I will try to draw out some of the implications of that. At the same time, however, I will try to show that the seeds for such a rift were planted in the very conceptual foundations of the Activity Theory tradition and will argue that there is scope for a renewal and a revitalization of that tradition in a rediscovery of the method, conclusions and implications of Marx's work and of Capital in particular.

\section{Marx and the origins of Activity Theory}

There is no doubt that Marx's ideas exerted a profound influence on Vygotsky, Rubinshtein, A $\mathrm{N}$ Leont'ev and Luria - the pioneers of culturalhistorical psychology and of Activity Theory. Central to that influence was Marx's Capital (Marx, 1976a), for a number of reasons. Firstly, Marx's characterization of human activity as our "species activity" - to be found on the very pages of Capital itself - is the very conceptual cornerstone of the activity-based approaches to psychology which are directly associated with Leont'ev and Rubinshtein. And, secondly, the very method of Capital itself, that is, its dialectical approach to the critical analysis of its subject matter (political economy) was a source of inspiration and a model for cultural-historical researchers.

On the first issue, Engeström and Miettinen (1999, p. 3) argue that:

"Marx's concept of labor, or production of use
values, was the paradigmatic model of human
object-oriented activity for Leont'ev when he
formulated the concept of activity. Drawing
directly on Marx and Engels, he emphasized the 
two mutually dependent aspects of mediation in labor activity".

The two aspects of mediation have to do with the fact that labour is "a process mediated by tools ... and at the same time mediated socially" (Leont'ev, 1981, p. 208 in Engeström \& Miettinen, 1999, p. 4). ${ }^{3}$

On the second issue, that of methodology, we all know that attempts have been repeatedly made, from early on in our tradition, to emulate Marx's analytical approach. For example, we are all familiar with Vygotsky's remark:

"I do not want to find out [about the nature of] the psyche for free - by clipping a few quotes - I want to learn from the whole of Marx's method how to build a science, how to approach the investigation of the psyche" (Vygotsky in Van der Veer \& Valsiner, 1991, p. 153)

In order to do so, Vygotsky argued, it was necessary "to create one's own Capital" (in Van der Veer \& Valsiner, 1991, p. 153). Vygotsky's extensive, and famous, presentation of his methodology of "analysis into units" (Vygotsky, 1986) is, arguably, one of the main fruits of his attempt to create such a psychological Capital under the influence of Marx's approach to the critique of political economy in which he begins from the commodity as the "cell" (or "germ cell") of value. ${ }^{4}$ Marx's method, known as the "method of ascent from the abstract to the concrete",

\footnotetext{
${ }^{3}$ At the risk of sounding pedantic, there are, from the very outset, grounds to challenge the validity of Leont'ev's interpretation of Marx's concept of human labour. For Marx, labour is not "mediated socially"; it is, quite simply, "species activity", i.e. it is what humans do. Nor is it "mediated by tools"; tools belong to its "simple elements", as we shall see below. To say that labour is mediated by tools is a bit like saying that walking is mediated by legs.

4 Although whether or not Vygotsky's "word meaning" could really be considered as a "cell" in the dialectical sense is another question (Jones, 2002).
}

explored in detail by Ilyenkov (1982) is considered by many authors to be a fundamental principle in Activity Theory research and theoretically informed practice. In recent years, as we shall see below, appeal has been made to Marx's general methodological principle in order to justify the use of a germ cell or unit of analysis of activity itself.

There is much more to Capital's influence, of course, than these general philosophical and methodological principles. Leont'ev, for instance, explored, if somewhat abstractly, the implications of Marx's analysis of capitalist production for concrete psychological investigation on the premise that:

"the psychological features of the individual consciousness can only be understood through their connections with the social relations in which the individual becomes involved" (1977, p. 191). "At first glance", he argued, "the immersion of research in this intricate picture may appear to divert it from the task of specific psychological study of the consciousness, and lead to the substitution of sociology for psychology" (1977, p. 191).

"But", he goes on, "this is not the case at all" (1977, p. 191) since "outside the system of these relations (and outside social consciousness) the existence of individual mentality, a psyche, in the form of consciousness is impossible" (1977, p.190). Psychology, in other words, cannot escape sociology; the psychological is inseparable from the social:

\footnotetext{
"although a scientific psychology must never lose sight of man's inner world, the study of this inner world cannot be divorced from a study of his activity and does not constitute any special trend of scientific psychological investigation" (1977, p. 202).
}

Capitalist production, he argued, had very specific consequences for human social relations and activity and, necessarily therefore, for 
psychological functioning and personality generally:

"The bulk of the producers, finally, were converted into hired labourers, whose only property was their capacity to work. The objective conditions of production were now opposed to them as another's property. They could therefore live and satisfy their vital wants only provided they sold their labour power, i.e. alienated their labour. But labour was the most intrinsic content of their life; they consequently had to alienate the very content of their life" (Leont'ev, 1981, p. 252).

Furthermore, the "incompleteness and inadequacy of consciousness" which results from this alienated condition "cannot be eliminated in any way other than through a practical change in the objective conditions that engender this inadequacy" (1981, pp. 260-261).

But if the influence of Capital is clear at this programmatic level, what is less clear is whether Leont'ev's principal theoretical innovation, namely his concept of activity as the basis for concrete psychological analysis, was consistent with Marx's own view of human activity and its relationship to the capitalist labour process. ${ }^{5}$

Let us now explore in some detail these two aspects of the link between Activity Theory and Capital: 1) activity as a concept and 2) activity as a unit of analysis.

\section{Activity as a concept}

For Marx, the category of activity was central to an understanding of what human beings do, of what they are, and what they can and will make of themselves. By "activity" in this general sense, Marx means "the life of the species", "life activity", "life engendering life" which he describes as "free, conscious activity", "man's species-character" (1976a, p. 86). Marx refers to activity in this sense by various terms, including

\footnotetext{
5 For an important critique of Leont'ev's position from a different perspective, see Stetsenko (2005).
}

"labour", "the productive life", "work", "the process of labour" or "the labour process" (1976a, p 86, p. 998). It is crucial, then, to recognise that Marx's terms "labour process" or "work" in this context do not refer to the particular, everyday activities in which people in a particular society, in a particular age, are engaged. "Work", as Marx puts it:

"is the eternal natural condition of human existence. The process of labour is nothing but work itself, viewed at the moment of its creative activity" (1976a, p. 998).

Labour, in this sense, "is a simple process between man and nature" whose "simple elements remain the same in all social forms of development" and which is not to be identified with "the process of social production" (Marx, 1909 , p. 1030) in the sense of a specific form or mode of production (e.g. capitalist production). These "simple elements of the labour process" (Marx, 1976a, p. 284) or, what is the same thing, "the universal features of the labour process" are "independent of every specific social development" (1976a, p. 998). Marx describes these 'simple elements' as follows:

"(1) purposeful activity, that is work itself, (2) the object on which that work is performed, and (3) the instruments of that work" (1976a, p. 284).

Again, it is important to note that Marx is not describing any particular, historical action; "activity" here is not equivalent to what we would call a "job". ${ }^{6}$ These "general features of the labour process" are

"all independent of every historical and specifically social conditioning and they remain valid for all possible forms and stages in the development of the processes of production. They are in fact immutable natural conditions of human labour.

\footnotetext{
${ }^{6}$ Cf Newman \& Holzman (1993, p. 44): "our day-to-day societally determined and commodified 'activities' are not activity at all in the Marxian, historical sense."
} 
This is strikingly confirmed by the fact that they hold good for people who work independently, i.e. for those, like Robinson Crusoe, who work not in exchange with society, but only with nature. Thus they are in fact absolute determinants of human labour as such, as soon as it has evolved beyond the purely animal" (Marx, 1909, pp. 1021-1022).

Thus, Marx's description of human labour, of our "species character", is not a description of, say, capitalist production any more than it is a description of feudal production: it says nothing at all about the one or the other, except that in both cases the labour process must be taking place otherwise everybody would be dead. But if this description tells us nothing at all about capitalist production specifically, then it can hardly serve as a model or framework either for the analysis of specifically capitalist production - capitalist "activity", we might say - or of the motives, capacities and abilities of individuals within capitalist society.

Marx's efforts in Capital are directed at showing what is historically specific to, unique to, the capitalist mode of production and at demonstrating thereby the necessarily transient nature of capitalist production. In capitalist production the labour process is there but it is fused with another process - with an activity in quite a different sense - which Marx refers to as "the valorization process" or "a process of creating value" (1976a, p. 293).

Capitalist production involves the production of commodities. These are things that are useful, and necessary to sustain life, but also have a value (expressed in their price). The capitalist process of production, then, is "the unity of the labour process and the process of valorization" (Marx, 1976a, p. 304). These two processes (or "activities") are not the same thing and must not be confused, conflated or equated. Indeed, they are opposite, antithetical processes:

"In the labour process looked at purely for itself the worker utilizes the means of production. In the labour process regarded also as a capitalist process of production, the means of production utilize the worker" (Marx, 1976a, p. 1008).

Marx explains in more detail:

"In the labour process the worker enters as worker into a normal active relationship with the means of production determined by the nature and the purpose of the work itself. He takes possession of the means of production and handles them simply as the means and materials of his work...The material conditions of labour now enter into a normal unity with labour itself; they form the material, the organs requisite for creative activity" (1976a, p. 1007).

He goes on:

"But production is also a process of valorization, and here the capitalist devours the labour-power of the worker, or appropriates his living labour as the life-blood of capitalism. Raw materials and the object of labour in general exist only to absorb the work of others, and the instrument of labour serves only as a conductor, an agency, for this process of absorption" (1976a, p. 1007).

It would be quite wrong, then, according to Marx to attribute to the "activity" of capitalist production, or indeed to any "activity" specifically conditioned by capitalist production relations, the attributes of the labour process as such, of "free, conscious activity" which is our "species character". For exactly this reason, it would be wrong, according to Marx, to simply and uncritically apply the term "activity" in the sense of the labour process to the "activities" involved in capitalist production or to any concrete, historically specific productive activity or sphere of work. To do so would be to hide the historically specific and transient features of the social production process behind the simple, universal, eternal, natural, "absolute determinants of human labour as such" (Marx, 1909, see above). It would be to disguise the process of valorization - the "activity" in which some people are exploited by others - as a "simple relation 
between man and nature" (Marx, 1909, see above).

It is absolutely central to Marx's work in Capital, indeed it is central to the whole of his being, to distinguish between the two sides or aspects of the capitalist production process - viz. human labour as such and the valorization process. His indictment of the bourgeois political economists is based on their "failure to comprehend the labour process as an independent thing and at the same time as an aspect of capitalist production" (Marx, 1976a, p. 1000). And much of Capital is devoted to showing how and why these two aspects are confused in the minds of political economists (as well as everybody else) and the consequences of "confusing the appropriation of the labour process by Capital with the labour process itself" (1976a, p. 998). Marx argues, for instance, that mixing up the features of the labour process as such with specific features of the capitalist labour process is "a very convenient method by which to demonstrate the eternal validity of the capitalist mode of production and to regard Capital as an immutable natural element in human production as such" (1976a, p. 998).

This confusion is, I believe, evident in the very foundations of Activity Theory and evident, consequently, in some of its contemporary variants, although the intention is certainly not to "demonstrate the eternal validity of the capitalist mode of production". As Engeström and Miettinen (1999, p. 3), noted earlier, argue: "Marx's concept of labor, or production of use values, was the paradigmatic model of human object-oriented activity for Leont'ev when he formulated the concept of activity". In other words, it would appear that Leont'ev, instead of approaching activity from the standpoint of its socio-historical specificity, proceeded to construct a full-blown theory of activity out of what Marx describes as 'independent of every specific social development' (Marx, 1976a, p. 998). It would seem that he assumed that what Marx sees as an aspect of the total social production process - an aspect which is in violent conflict with other aspects - can be taken as a general characterization of the process overall and of all the separate 'activities' which make it up. In other words, Leont'ev has constructed a general model of any kind of human activity whatsoever out of determinations which Marx intended to apply only to activity in the sense of the labour process - the "simple relation between man and nature". To do so, Leont'ev had to add in a few more concepts to the abstract determinants Marx gave, including the distinction between "collective activity and individual action" (Engeström and Miettinen, 1999, p. 44), an addition which muddies the theoretical waters still further.

We find exactly the same approach in Davydov (1999) ${ }^{7}$ who also takes Marx's concept of activity (in the sense of the labour process) to apply indifferently to any particular social activity:

"Thus one can regard activity as an initial category that determines the specific character of people's social being. The social laws can reveal themselves only in activity and through it" (1999, p. 41).

But activity in Marx's sense, we should recall, does not at all "determine the specific character of people's social being", but is, rather, "independent of every historical and specifically social conditioning" (Marx, 1909, see above). What "determines the specific character of people's social being" under capitalist conditions (at least in the most general terms) is not labour, productive activity, or (what is a different name for the same thing) the "labour process" as such but the capitalist labour process ("the appropriation of the labour process by capital") which is a different thing entirely. And that is

Davydov argues that "Marx's philosophical and sociological concepts should be kept separate from his more specific economic and political views" (1999. pp. 39-40). I could not disagree more and would argue that this statement betrays some degree of misunderstanding of Marx's ideas in general and of Capital in particular. 
why the features of activity in Marx's sense cannot be applied, or be used to model, the specific properties of "activity" within capitalist conditions (or, indeed, in the conditions of any specific social system).

Exactly the same confusion is to be found in $\mathrm{S}$ L Rubinshtein's approach (1999), I believe, although I will not try to demonstrate that here. And I believe it is also to be found in the conceptual models of activit' to be found in the work of Yrjö Engeström and colleagues which I will examine more closely in the next section.

Engeström, I should emphasise, has done much to stress the continuity between activity theory and Marx's ideas. He has also acknowledged the relevance of Marx's work in Capital for theory and practice today, and, in particular, for our understanding of the internal contradictions within "activity systems", as the following passage makes clear:

"The primary inner contradictions reflect the basic contradiction characteristic to the socio-economic formation as a whole. In capitalism, the basic contradiction is the dual nature of commodities, the tension between the use value and the exchange value. In different activity systems, this fundamental tension appears in different forms, as the primary contradiction of that particular activity. This primary contradiction resides in each component of the activity system. For example, in bureaucratic and rationalized medical work activity, doctors typically experience a constant latent tension between their role as gatekeepers and cost-efficient producers on the one hand, and as healers or consultants on the other hand" $(1990, \mathrm{p}$. 84).

Nevertheless, there are grounds for concern in this interpretation of Marx's work. First of all, the basic contradiction in capitalism is not the dual nature of commodities. While capitalist production necessarily involves the making of commodities, the making of commodities does not make capitalist production: "The fact that it produces commodities does not distinguish it from other modes of production" (Marx, 1909, p. 1025).

Capitalist production, rather, "is marked from the outset by two peculiar traits" (Marx, 1909, p. 1025). First of all, "the laborer himself acts in the role of a seller of commodities" so that "wage labor is the typical character of labor" (1909, p. 1025). It follows that "the relation between wage labor and capital determines the entire character of the mode of production" (1909, p. 1025, my emphasis). The second "specific mark of the capitalist mode of production" is "the production of surplus-value as the direct aim and determining incentive of production. Capital produces essentially capital, and does so only to the extent that it produces surplus-value" (Marx, 1909 , p. 1026, my emphasis). In other words, as Ilyenkov puts it:

"The real historical beginning of the development of capital, as Marx showed, was the point at which Capital began to build its body out of the unpaidfor labour of the wage worker. Only at this point does its specific concrete history begin" (1982, p. 214).

Commodities, then, are a prerequisite for capitalist development, belonging to the "'antediluvian premises of capitalist development, to its "prehistoric" conditions. As concrete historical forms of being of capital, reflecting in their movement its specific history, they are products of capital itself" (Ilyenkov, 1982, p. 211, my emphasis).

It would appear, then, that the reasons why Marx began his analysis in the first volume of Capital with the commodity have been forgotten or misunderstood: the basic contradiction of capitalist production is not that within the commodity as such - the commodity is not even specific to capitalist production! I return to the point in the next section.

Incidentally, this also means that medical practice, in some European countries at least, does not provide a typical instance of the workings of 
capitalist production although it inevitably depends on both a supply of commodities and on wage-labour. Indeed, public health services, generally speaking, do not provide cases of capitalist production at all to the extent that they are spheres of consumption of goods and services rather than of production of surplus value. The relatively benign atmosphere and circumstances to be found within some systems of public health care, when viewed narrowly, do not, therefore, reflect the "basic contradiction" of capitalism and, for that reason, can hardly be taken as a 'model' of specifically capitalist economic processes. (Nor, of course, given their social specificity, can they be taken as cases or examples of activity in general). But public health care systems, like public education systems, operate, of course, within the overall system of capitalist economic and political relations and, therefore, cannot be properly understood without concrete analysis of their place within these relations. Their position in this system naturally makes them a constant site of political and economic contestation. In particular, they are a tempting target for appropriation by private Capital and the struggle to defend them must, therefore, take account of these deep and powerful motive forces of capitalist production. ${ }^{8}$

\section{Activity as a unit of analysis}

Much has been made of Marx's analytical method in Capital in terms of its relevance for understanding human activity and its problems and prospects. Ilyenkov's work (1982), dedicated to explicating and defending this method - the method of "ascent from the abstract to the concrete" - is well known and celebrated within the CHAT tradition. This method is often referred to as one involving "germ-cell models" where "the most famous instance of this kind of analysis

\footnotetext{
${ }^{8}$ See Monbiot (2001) for a careful exposé of the UK Labour government's mission to privatize the National Health Service and the public education system.
}

is the identification of commodity as the germcell of the capitalist socio-economic formation" (Engeström, 1993, p. 53). Sometimes the term "unit of analysis" (echoing Vygotsky's famous exposition of his own methodology in Vygotsky, $1986)$ is used in reference to the "germ-cell" method, as in Miettinen (2000, p. 112):

\begin{abstract}
"Marx traced the germ cell of a capitalist society (commodity and value), and then drew the whole system of concepts and determinations to uncover the developmental dynamics of capitalism. The unit of analysis is the capitalist society as a whole". ${ }^{9}$
\end{abstract}

However, despite the reference to Marx's procedure in Capital, Engeström and Miettinen have proposed a new 'unit of analysis' for contemporary Activity Theory, one which will allow us to grasp the contradictions and complexities in today's working practices and to appreciate "the creative and dynamic potential of concrete work process and technologies" which "remains underdeveloped" in Marx's work (Engeström and Miettinen, 1999, p. 5). That new unit of analysis can be found "in the concept of object-oriented, collective, and culturallymediated human activity, or activity system" (Engeström and Miettinen, 1999, p. 9). Such a unit of analysis will be "a concrete work activity" (Miettinen, 2000, p. 114) such as, say, a medical practice, health care system, adult education provision, or a scientific laboratory. In order to uphold Marx's "germ cell methodology" it seems, then, that we have to part company with Marx's own germ cell, namely the commodity. Let us take a step back and consider what is at stake.

If such concrete work activities are, indeed, units of analysis (without worrying about what they could be units of analysis of) then it is a wonder why Marx himself didn't adopt this approach. Why did he not begin, in Capital, by breaking down contemporary capitalist society

\footnotetext{
9 See Jones $(2004,2009)$ for detailed critical commentary on these passages.
} 
into its activity 'units' - here is tailoring, here watch-making, match-making, here candlestickmaking, here is teaching, here banking, here surgery, here is factory work, here politics, etc and then proceed to join them all up and examine the connections between them? The reason is simple: to do so would be to incorporate into our basic conceptual "units" the confusion which Marx is making every effort to avoid.

On this 'unit' approach, the specific and 'peculiar' traits of capitalist production noted above - the traits which determine the entire character of the society in which capitalist relations obtain - have been removed from the outset and cannot be coherently put back. For example, to call the activity taking place under capitalist conditions within the match factory "match-making" is already to be guilty of "confusing the appropriation of the labour process by Capital with the labour process itself" (Marx, 1976a, p. 998). Matches may be being produced by the workers in the match factory, but the crucial product is not matches but surplus value. As Marx explains:

"The capitalist labour process does not cancel the general definitions of the labour process. It produces both product and commodity. Labour remains productive as long as it objectifies itself in commodities, as the unity of exchange-value and use-value. But the labour process is merely a means for the self-valorization of capital" (Marx, 1976a, p. 1039, my emphasis).

Marx's point is that you must begin from the commodity, not from the labour process or from some abstract definition of activity, in order to understand capitalist production. Why? Because the labour process is there (commodities are produced and consumed as useful things) but it is already caught up by and subordinated to another process, viz. the process of producing value. It is the commodity - this socio-historically specific form of the product of labour - which is a necessary condition for capitalist production and no other starting point will lead you to capital, i.e. to the "peculiar traits" of specifically capitalist production. Indeed, if you do not go through the analytical journey which Marx makes - otherwise known as "the method of ascent from the abstract to the concrete" - the peculiar complexities and mystifying appearances of capitalist production will bamboozle you. Marx argues:

"Vulgar economy really does nothing else but to interpret, in doctrinaire fashion, the ideas of persons entrapped in capitalist conditions of production and performing the function of agents in such production, to systematize and to defend these ideas. We need not wonder, then, that vulgar economy feels particularly at home in the estranged form of manifestation, in which economic conditions are absurd and complete contradictions, and that these conditions appear so much more self-explanatory to it, the more their internal connection is concealed. So long as the ordinary brain accepts these conceptions, vulgar economy is satisfied. But all science would be superfluous, if the appearance, the form, and the nature of things were wholly identical". (1909, p. 951)

Marx's own work, therefore, particularly the third volume of Capital, is focussed on:

"locating the concrete forms growing out of the movements of capitalist production as a whole and setting them forth. In actual reality the capitals move and meet in such concrete forms that the form of the capital in the process of production and that of the capital in the process of circulation impress one only as special aspects of those concrete forms. The conformations of the capitals evolved in this third volume approach step by step that form which they assume on the surface of society, in their mutual interactions, in competition, and in the ordinary consciousness of the human agencies in this process" (Marx, 1909, pp. 37-8).

To begin, then, from "concrete work activities"' as units of analysis is to depart from Marx's Capital - from its conclusions as well as its method. It is to begin and end with those forms 
of activity which are manifest "on the surface of society" rather than to seek to understand the historical specificity - and, therefore, the transitory quality - of those forms of social intercourse from which these surface forms are produced and which these forms also disguise and conceal. The motor of the whole system of production - the pumping out of surplus value from living labour - is entirely absent on the surface as are, consequently, the complex and contradictory connections and interactions which are driven by capital independently of the will and wishes of individuals and which bind all activities, indeed all people throughout the world, together in alienated and alienating conditions of life and work. Thus, the apparently concrete work 'activity' of a particular professional sphere or branch of the social division of labour is actually the most abstract and, therefore, inappropriate place to look for a clear understanding of the inner contradictions of social life.

To compound the problem, we see that the terms in which this new unit of analysis is described - object-oriented, collective, and culturally-mediated human activity, or activity system - reproduce in somewhat modified form the simple elements of the labour process as Marx describes in Capital. That is, the terms describing work as "free, conscious activity", human "species character", "productive life-activity", etc are to be applied to empirical instances of work under conditions of capitalist production, the very thing Marx warns against. Thus, to be very blunt, taking "concrete work activities" or "activity systems" as units of analysis is, in Marx's terms, to introduce the categories and methods of "vulgar economy" (or bourgeois sociology) into the cultural-historical tradition through the back door.

The attributes of human activity, or the labour process, as Marx understood it, have been mistakenly made into a model for the analysis of work 'activities' which are part of the fabric of the capitalist production process. As a result, specifically capitalist labour processes are normalized and even naturalized in the sense of being wholly disguised by general, transhistorical labels. In this way, both the specificity and transitoriness of capitalist production relations are concealed from view and the task of freeing the labour process - human activity from the chains of Capital cannot be posed.

Langemeyer and Roth (2006), Avis (2007), and Warmington (2008) have also approached the problem of the continuity between the Marxist tradition and Activity Theory today in critical fashion and have drawn conclusions which complement the analysis presented here. Avis (2007, p.175), for example, argues that "the notion of conflict and social antagonism is underplayed" in Engeström's Activity Theory, with the consequence that "the notion of transformation becomes truncated". Warmington (2008, p. 17) calls for a renewal "of activity theory's theoretical and methodological framework" on the basis of an understanding of Marx's work. The peril, as he explains, "is that, in current activity theory, Marxist notions of contradictions in the labour process become domesticated in the service of "soft" system adaptation".

Paul Adler (2006, 2007), on the other hand, finds Engeström's Activity Theory to be "a useful framework" for providing "a more fine-grained account of the production process" from his own "paleo-Marxist' point of view" (Adler, 2007, p. 1329). In order to demonstrate this, Adler begins from a model of what Marx calls "production in general", which is "trans-historical insofar as it does not acknowledge any more specific, historically-bounded, "concrete" determinations' (2007, p. 1330). The next step is as follows:

"We move from this abstraction towards the concrete by overlaying on this model a set of determinations that mark production as specifically capitalist. Of these, the most fundamental is the contradiction between use-value and exchangevalue of which the commodity is the germ. This 
contradiction is reflected in each of the elements of the labour process" (2007, p. 1330).

However, Adler's proposal to begin from "production in general" is, once again, at odds with Marx's own method of beginning from the commodity. Despite Adler's cogent exposition of key aspects of Marx's analysis (including the distinction between labour process and valorization process) and his forthright commitment to affirm the contemporary relevance of Marx's ideas, there are, therefore, in my view, certain key problems in his attempt to reconcile these ideas with the methodology of Activity Theory.

The first problem is that Adler takes "the contradiction between use-value and exchangevalue" as the most fundamental contradiction within capitalist production whereas Marx, as we have already seen, takes the relation between wage labour and capital as fundamental. The consequence of this is that the production of surplus-value becomes disguised or camouflaged within labour process terminology rather than being made visible as "the direct aim and determining incentive of production" (Marx, above).

The second problem manifests itself in the view that the concreteness of capitalist production can be grasped by "overlaying ... a set of determinations that mark production as specifically capitalist" (Adler, 2007, p. 1330) onto the determinations of the labour process in general. For Marx, by contrast, the relationship between the labour process and the valorization process is not at all one of "overlaying". Marx, instead, speaks of the "appropriation of the labour process by capital" (1976a, p. 998) or of the "exploitation of a social labour process" (1976b, p. 449) in capitalist production. It follows then, that one cannot talk about those activities involved in the "exploitation of a social labour process" in the conceptual terms applicable to the labour process itself. Such a process of exploitation not only "transforms the nature of the labour process and its actual conditions" (Marx, 1976a, pp. 1034-5) but, in doing so, creates all kinds of "activities" which are completely parasitic on, or violently antithetical to, the labour process and which should not be dignified by being described in the same conceptual terms.

In essence, I believe that Adler's proposal involves a misunderstanding of aspects of Marx's method of "ascent from the abstract to the concrete". In fact, ascending from the abstract does not at all mean beginning from an abstraction - from an abstract, general idea, definition or concept to which "concrete" determinations are then progressively added. As Marx himself puts it:

"In the first place, I do not proceed on the basis of "concepts" ... What I proceed from is the simplest social form in which the product of labour in contemporary society manifests itself, and this is as "commodity". That is what I analyse, and first of all to be sure in the form in which it appears" (1976b, p. 214, emphasis in original).

Thus, Marx's "ascent from the abstract" begins, however paradoxical this may seem, with "the 'commodity' - the simplest economic concretu"' (1976b, p. 215) and builds from there to reconstruct the logic of the development and dynamic of capitalist production.

Adler may well disagree with these points, however, and a thorough debate around these issues between all interested parties would therefore make for an important step forward in the theoretical development of the Activity Theory tradition.

\section{Implications and prospects}

Although this paper has concentrated on what may appear to be esoteric issues of theory and methodology, I would hate to create the impression that these are matters of theory alone. Marx's distinction between the labour process and the valorization process is not an academic hair splitting exercise. He wants to show how human 
potential - the potential to make our world a world truly fit for a human way of life - is present within capitalist production processes but is locked up, constrained, diverted and perverted by being subordinate to another process in which the many are exploited by the few. As Mészáros explains:

"To Marx, in contradistinction to the reformer, economic investigations do not serve as theoretical grounds of an economic action, but of a political one. He is interested in problems of economy only insofar as they reveal the complex hierarchy of the structure that he wants to see positively transcended" (Mészáros, 1970, pp. 126-7).

\section{And further:}

"The point about labour producing itself and the worker as a commodity is of the utmost importance for the understanding of Marx's position on the question of supersession. Since the very foundation of human existence and of all human attributes is the purposive productive activity which has ... a relative priority over the concept of man, if one cannot present labour in a historical framework, showing the actual process in which purposive productive activity becomes wage-labour (or "alienated labour"), one has no ground for envisaging a supersession" (Mészáros, 1970, p. 125).

Marx, then, contrary to the claims by Engeström and Miettinen (1999, p. 5) did not fail to appreciate or to investigate "the creative and dynamic potential of concrete work process and technologies". On the contrary. What Marx did was to show that our human potential, our very "species character", was to be found in "the creative and dynamic potential of concrete work process and technologies". But, and here is the crucial thing, he showed that this creative force which he called the labour process - must, at all costs, be distinguished from the appropriation of this process by capital. And this theoretical distinction was in itself nothing but the recognition of the practical possibility of releasing that creative and dynamic potential from the destructive and dehumanising clutches of capitalist production.

This is not to deny either that our everyday working environments, as Engeström and colleagues rightly point out, offer a wealth of opportunities for learning and invention. But what people learn varies very much according to circumstance. Certainly, people are constantly learning new ways - more efficient and more humane perhaps - to work with one another. But at the same time, some people turn up for work to learn that they are out of a job or have had their pay cut. Some learn that their efforts to improve the working and living conditions of their fellow human beings will end in arrest, incarceration, or even worse. Some learning takes place despite the general inhumanity of our circumstances. But some learning takes place because of it. The formation and growth of trade unions and the international labour movement is therefore itself a monumental tribute to the power of workplace learning.

In conclusion, Marx understood human activity not as a unit of analysis of empirically given activities within capitalist society, in the sense of a theoretical model of such activities. His conception of activity was an affirmation of the human potential for creative, life-affirming communion and transformation which had grown up inside, and partly because of, capitalist production, and, for that reason, his perspective entailed a critique of dominant views of the nature, history and fate of capitalist production. His conception of activity was both the criterion against which political and economic actions could be measured and the aim of human emancipation from class division and exploitation. It was not a model of activity under existing conditions but a call to arms, a call for social transformation, which was heard by the pioneers of the cultural-historical tradition and which, as Stetsenko (2008) and Stetsenko and Arievich (2004) have argued, is of vital 
significance for the development of our tradition today.

\section{References}

Adler, P. S. (2006). From Labor Process to Activity Theory. In P. Sawchuk, N. Duarte, \& M. Elhammoumi (Eds.). Critical Perspectives on Activity: Explorations across Education, Work and Everyday Life. Cambridge: Cambridge University Press.

Adler, P. S. (2007). The Future of Critical Management Studies: a Paleo-Marxist Critique of Labour Process Theory. Organization Studies 28, 1313-1345.

Avis, J. (2007). Engeström's version of activity theory: a conservative praxis? Journal of Education and Work, 20 (3), 161-177

Davydov, V. V. (1999). The content and unsolved problems of activity theory. In Y. Engeström et al (Eds.) Perspectives on Activity Theory, Cambridge: Cambridge University Press, 3952.

Engeström, Y. (1990). Learning, Working and Imagining: Twelve Studies in Activity Theory. Helsinki: Orienta-Konsultit.

Engeström, Y. \& Miettinen, R. (1999). Introduction. In Y. Engeström et al (Eds.) Perspectives on Activity Theory. Cambridge: Cambridge University Press.

Ilyenkov, E. V. (1982). The Dialectics of the Abstract and the Concrete in Marx's 'Capital'. Moscow: Progress.

Jones, P. E. (2001). The ideal in culturalhistorical activity theory: issues and perspectives. In S. Chaiklin (Ed.) The Theory and Practice of Cultural-Historical Psychology. Aarhus: Aarhus University Press.

Jones, P. E. (2002). 'The word becoming a deed': the dialectic of 'free action' in Vygotsky's 'Tool and sign in the development of the child'. In D. Robbins \& A. Stetsenko (Eds.) Voices within Vygotsky's Non-classical
Psychology: Past, Present, Future. New York: Nova Science, 143-159.

Jones, P. E. (2003). Activity theory and the Marxian legacy. Paper presented at the Conference 'Marxism and Education: Renewing the Dialogue'. Institute of Education, London.

Jones, P. E. (2004). Ilyenkov and methodological issues in Activity Theory today. Unpublished manuscript. Sheffield Hallam University.

Jones, P. E. (2009). Ilyenkov and methodological issues in 'activity theory' today. (In Russian). Logos 1 (69), 133-150.

Langemeyer, I. \& Roth, W-M. (2006). Is Cultural-Historical Activity Theory threatened to fall short of its own principles and possibilities as a dialectical social science? Critical Social Studies - Outlines, 8:2, 20-42.

Leont'ev, A. N. (1977). Activity and consciousness. In Philosophy in the USSR. Problems of Dialectical Materialism. Moscow: Progress, 180-202.

Leont'ev, A. N. (1981). Problems of the Development of the Mind. Moscow: Progress.

Marx, K. (1909). Capital. A Critique of Political Economy. Volume Three. Chicago: Charles H Kerr \& Co.

Marx, K. (1976a). Capital. A Critique of Political Economy. Volume One. Penguin.

Marx, K. (1976b). Value: Studies by Marx. London: New Park Publications.

Mészáros, I. (1970). Marx's Theory of Alienation. London: Merlin Press.

Miettinen, R. (2000). Ascending from the abstract to the concrete and constructing a working hypothesis for new practices. In V. Oittinen (Ed.) Evald Ilyenkov's Philosophy Revisited, Helsinki: Kikimora Publications, 111-129.

Monbiot, G. (2001). Captive State: the Corporate Takeover of Britain. London: Pan Macmillan. 
Newman, F. \& Holzman, L. (1993). Lev Vygotsky: Revolutionary Scientist. London: Routledge.

Rubinshtein, S. L. (1999). Foundations of General Psychology. (In Russian). St Petersburg: Piter.

Sawchuk, P. (2006). Activity \& Power: Everyday Life and Development of Working-Class Groups. In P. Sawchuk, N. Duarte, \& M. Elhammoumi (Eds.) Critical Perspectives on Activity: Explorations across Education, Work and Everyday Life. Cambridge: Cambridge University Press.

Stetsenko, A. (2005). Activity as Object-Related: Resolving the Dichotomy of Individual and Collective Planes of Activity. Mind, Culture, and Activity, 12 (1), 70-88.

Stetsenko, A. (2008). From Relational Ontology to Transformative Activist Stance on Development and Learning: Expanding Vygotsky's (CHAT) Project. Cultural Studies of Science Education, 3 (2), 471-491.

Stetsenko, A. \& Arievitch, I. M. (2004). The Vygotskian collaborative project of social transformation. History, politics, and practice in knowledge construction. Critical Psycho$\log y, 12,58-80$.

Van der Veer, R. \& Valsiner, J. (1991). Understanding Vygotsky. A Quest for Synthesis. Oxford: Blackwell.

Vygotsky, L. S. (1986). Thought and Language. A. Kozulin (Ed.). Cambridge, Mass: MIT Press.

Warmington, P. (2008). From 'activity' to 'labour': commodification, labour power and contradiction in Engeström's activity theory. Critical Social Studies - Outlines, 10: 2, 4-19. 